Journal of Mechanical Engineering and Sciences

ISSN (Print): 2289-4659; e-ISSN: 2231-8380

Volume 12, Issue 1, pp. 3515-3528, March 2018

(C) Universiti Malaysia Pahang, Malaysia

DOI:https://doi.org/10.15282/jmes.12.1.2018.18.0312

\title{
Performance analysis of immobilized and co-immobilized enriched-mixed culture
} for hydrogen production

\author{
Astrilia Damayanti $^{1,2, *}$, Sarto $^{2}$, Wahyudi B. Sediawan ${ }^{2}$, Siti Syamsiah $^{2}$ \\ ${ }^{1}$ Department of Chemical Engineering, Faculty of Engineering, Universitas Negeri \\ Semarang, Kampus Sekaran, Gunungpati, Semarang, Indonesia \\ Email: astrilia.damayanti@mail.unnes.ac.id \\ Phone/Fax : +62-8508101-8508009 ext.114 \\ 2 Department of Chemical Engineering, Faculty of Engineering, Universitas Gadjah \\ Mada, Jalan Grafika No. 2, Yogyakarta, Indonesia
}

\begin{abstract}
This paper presents an experimental investigation on using mixed culture for immobilization and co-immobilization for hydrogen production. The shape and diameter of the beads were investigated. Hydrogen was produced from 10 g.L ${ }^{-1}$ glucose in anaerobic batch using immobilized mixed culture with extrusion dripping method. The alginate concentrations as immobilization material were $1 \%, 2 \%$, and $3 \%$. The mixed culture had three different biodigester sources consisting of cow dung, tofu waste, and fruit waste. The pretreatment of each mixed culture was acidification and enrichment. Then the mixed culture were mixed with immobilization material and inserted into a syringe, then dropped into $0.1 \mathrm{M} \mathrm{CaCl}_{2}$. Activated carbon was added to alginate (coimmobilization) with ratio $1: 1$. The results showed that bead using $1 \%$ and $2 \%$ alginate concentrations were a pear-shaped. The highest concentration of hydrogen $\left(\mathrm{mol} \mathrm{H}_{2} / \mathrm{mol}\right.$ glucose) was 0.029 for immobilized beads with $2 \%$ alginate concentration and the lowest hydrogen $\left(\mathrm{molH}_{2} / \mathrm{mol}\right.$ glucose) was 0.009 for immobilized beads with $3 \%$ alginate concentration. Acetic acid was the most dominant. The highest VFA (mg.L ${ }^{-1}$ ) was 695.85 for immobilized beads with $3 \%$ alginate concentration (acetic acid 271.49; propionic acid 163.33; isobutyrate acid 123.45; butyric acid 137.57). Most hydrogen was produced from $2 \%$ alginate concentration and spherical-shape.
\end{abstract}

Keywords: immobilization; mixed culture; alginate; activated carbon; beads; hydrogen. 


\section{INTRODUCTION}

Dwindling fossil fuel sources with its products in the form of greenhouse emissions make it necessary to search for alternative energy sources [1][2][3]. Hydrogen is a clean fuel because the final combustion product is water and calorific value is 143 GJ tonne ${ }^{-1}$ [4]. Hydrogen can be produced by glucose fermentation through the metabolic pathways of the microbes. Microbial conversion of substrate to $\mathrm{H}_{2}$ and volatile fatty acid (VFA) [1][5][6][7][8]. Hydrogen production through anaerobic fermentation has advantages over the other processes because it has the potential to use wastewater and organic wastes[9]. Anaerobic fermentation stages involve hydrolysis of complex organic materials into simple compounds (glucose), followed by acidogenesis facilitated by acidogenic bacteria to simpler compounds produced carbon dioxide, hydrogen, and VFA such as butyrate and propionate acid. The last stage, acetogenesis occurred by acetogenic bacteria which is VFA is converted into acetic acid, carbon dioxide, and hydrogen [10].

Natural mixed culture is often chosen for fermentation because of its affordability and ease of access [11]. Amekan et al. (2014) [12] investigated that the influence of the mixed culture of three biodigester sources towards the production of hydrogen from melon waste in batch. The results showed that the combination of the mixed culture of three different biodigester sources consisted of cow dung, tofu waste, and fruit waste produced the highest hydrogen $\left(231.02 \mathrm{~mL}_{\mathrm{gVS}}{ }^{1}\right)$, compared with of one and two biodigester sources. Unfortunately, mixed culture contains bacterial diversity so that a process is needed to obtain the hydrogen-producing bacteria (HPB) such as acidification method [13][14]. Hu et al. (2008) [15] investigated that acidification pretreatment for sewage sludge increased hydrogen production rates. To increase the production rate and hydrogen yields, it was enriched by HPB[16] because HPB enrichment made HPB more stable on its life cycle [17].

The hydrogen production used as suspended cells are less preferred in biohydrogen production because suspended cells are prone to washout and cannot prolong during continuous modes[18], they cannot reusable and withstand the inhibitors during the fermentation process [19]. Therefore, the way to overcome its problem is immobilized cells[18][19]. Hydrogen production using immobilized mixed culture are four times more than suspended cells [20][21]. Hydrogen concentration using cell immobilized with a mixture matrix consisted of sodium alginate and activated carbon or sodium alginate and polyurethane were $50 \%$ of total biogas [22].

The immobilized matrix mostly used for biohydrogen production is alginate because of its affordability, simplicity, biocompatibility[23], less cost, easy to use, and highly accessibility [24]. Merugu et al.(2012) [25] studied that the maximum hydrogen 
production were occurred between the fifth and sixth day by immobilized pure culture with calcium alginate as a matrix. Co-immobilized pure culture using $2 \%$ sodium alginate and $0.3 \%$ activated charcoal concentration with dripping extrusion method produced $50 \mathrm{~mL}$ hydrogen [26]. The optimum sodium alginate concentration was $2 \%$ which used immobilized mixed culture [26] and municipal sewage sludge [22][21] for biohydrogen production. Co-immobilization used two matrices where the activated carbon was an inert support matrix could strengthen the structure of the alginate beads [22][27].

Beads characterizations of size and shape was an important factor in hydrogen production. Azbar and Kapdan (2012) [28] stated that the alginate beads' diameter was a very influential factor in immobilized cell, especially for hydrogen production. Beads diameter up to $6 \mathrm{~mm}$ caused efficient anaerobic hydrogen production, whereas beads diameter more than $6 \mathrm{~mm}$ caused substrate availability for limited cell metabolism and reduced hydrogen production. Beads morphology significantly affected mechanical stability. Al-Hajry et al. (1999)[29] stated that if the beads are not spherical, it would reduce beads strength. The most convenient and popular method to produce spherical beads was extrusion dripping [30]. Factor affecting to the shape and size of the beads could be qualitatively analysed used a dimensionless number of Ohnesorge (Oh) [31]. The Ohnesorge number is related to the viscosity, density, and surface tension of the fluid [32].

Up to now, there is no research on characterisation of alginate beads produced by the extrusion dripping method from enriched-mixed culture to the production of hydrogen. Therefore, this study aims to determined and verify the characterisation of co-immobilized and immobilized beads.

\section{MATERIAL AND METHODS}

\section{Immobilized Material Characteristics}

Sodium alginate powder (12 g) (technical) characteristics were 47.11\% (5.65 g) water content and $88.88 \%$ (10.67 g) ash content. Activated carbon (Merck) was analysed by Brunauer-Emmett-Teller (BET) method consisting of surface area, porosity total volume, and average porosity diameter were $738.524 \mathrm{~m}^{2} \mathrm{~g}^{-1}, 0.6365 \mathrm{~cm}^{3} \mathrm{~g}^{-1}$, and 1.724 $\mathrm{nm}$, respectively. The pore size wass measured by Barrett-Joyner-Halenda (BJH) method consisting of $2-50 \mathrm{~nm}(86.27 \%)$ and $<2 \mathrm{~nm}(13.73 \%)$.

\section{Substrate and Composition Medium}

Glucose $\left(10\right.$ g. $\left.\mathrm{L}^{-1}\right)$ was used as a carbon source. The composition of the enrichment medium and fermentation nutrients used were similar to previous experiment [33]. 


\section{Mixed Culture}

Mixed culture was obtained from biodigesters consisting of cow dung (ECDD), tofu waste (ETD) and fruit waste (FW) in Yogyakarta, Indonesia. Mixed culture characteristics are shown in Table 1.

Table 1. Mixed culture characteristic

\begin{tabular}{cccc}
\hline Mixed culture & $\mathrm{pH}$ & $\mathrm{TS}, \mathrm{mg} \cdot \mathrm{mL}^{-1}$ & $\mathrm{VS}, \mathrm{mg} \cdot \mathrm{mL}^{-1}$ \\
\hline ETD & 7 & 4.71 & 3.27 \\
FW & 5 & 7.49 & 5.61 \\
ECDD & 7 & 10.87 & 8.71 \\
\hline
\end{tabular}

The treatment of mixed culture prior to the fermentation process was acidification and enrichment wherein firstly, enrichment is carried out on each biodigester and finally, all of the third enrichment were mixed.

The mixed culture was pre-treated to deactivate the hydrogenotrophic methanogens prior to use in the HPB enrichment. This deactivation was conducted by adding $2 \mathrm{M} \mathrm{HCl}$ to $\mathrm{pH} 3$ and keeping it for 24 hours. The $\mathrm{pH}$ was then further adjusted back to $\mathrm{pH} 7$ by adding $2 \mathrm{M} \mathrm{NaOH}$ [13]. HPB enrichment was done in $100 \mathrm{~mL}$ vials with $45 \mathrm{~mL}$ volume. Enrichment of mixed cultures was performed three times. Then, each mixed culture was taken as $2 \mathrm{~mL}$ to be mixed in the medium enrichment for 24 hours.

\section{Preparation of Immobilized and Co-immobilized Mixed Culture Immobilized Mixed Culture}

As much as $45 \mathrm{~mL}$ enriched-mixed culture centrifuged at $4000 \mathrm{rpm}$ for 10 minutes and then it was harvested and washed twice by using $10 \mathrm{~mL}$ of $0.97 \% \mathrm{NaCl}$. The three sources of mixed culture were combined with $1 \mathrm{~g}$ sodium alginate $(1 \% \mathrm{w} / \mathrm{v})$ and $100 \mathrm{~mL}$ of $0.97 \% \mathrm{NaCl}$. The mixture were put into the syringe and dropped into $0.1 \mathrm{M} \mathrm{CaCl}_{2}$ to make beads. These beads and $\mathrm{CaCl}_{2}$ solution were stored at $4{ }^{\circ} \mathrm{C}$ for 30 minutes. The beads were washed with distilled water before used. The immobilized beads using $2 \%$ and $3 \%$ alginate concentrations were made by under the same experimental conditions as $1 \%$ alginate concentration.

\section{Co-immobilized Mixed Culture}

One gram activated carbon (Merck) was added to the three mixed culture source with $50 \mathrm{~mL}$ of $0.97 \% \mathrm{NaCl}$. Biodigesters enrichment, activated carbon, and $50 \mathrm{~mL}$ of $0.97 \%$ $\mathrm{NaCl}$ were mixed then combined them with solution comprising $1 \mathrm{~g}$ of sodium alginate 
$(1 \% \mathrm{w} / \mathrm{v})$. Then, the mixture was put into a syringe. The ratio to make the co-immobilized beads with added activated carbon to alginate was 1:1.

\section{Batch Hydrogen Production}

Production medium consists of $60 \%$ of nutrients $(30 \mathrm{~mL}), 30 \%$ of the substrate $(15 \mathrm{~mL})$, and $10 \%$ mixed culture $(5 \mathrm{~mL})$ of working volume [12]. The number of beads used was the same as the previous experiments [33]. The average weight of immobilized beads and coimmobilization for the three concentrations used in hydrogen production were $3 \mathrm{~g}$ and $3.5 \mathrm{~g}$, respectively. HPB of ca. 0.3945 g.L ${ }^{-1}$ for immobilization and 0.635 g.L $\mathrm{L}^{-1}$ for coimmobilization. The initial $\mathrm{pH}$ in each vial was determined before flushing with $\mathrm{N}_{2}$ for 3 minutes. The vials were kept in incubator and the temperature was maintained at $36^{\circ} \mathrm{C}$ (MRK I B-S, U.K). Analysis of hydrogen and VFA was conducted at the twentieth hour. All treatments were conducted in two replicates. The co-immobilized beads were used for hydrogen production under the same experimental conditions with $1 \%$ immobilized beads.

\section{Analytical Methods}

Hydrogen was analyzed using gas chromatography (GC) Shimadzu GC 8A (Japan) equipped with a thermal conductivity detector (TCD) and molecular column sieve 5A (MS-5A) with 5m column length.Temperature of column, detector, and injector were set at $60^{\circ} \mathrm{C}, 70^{\circ} \mathrm{C}$, and $70^{\circ} \mathrm{C}$, sequentially. Nitrogen was used as carrier gas with an inlet pressure of $100 \mathrm{kPa}$. VFA (acetic acid, butyric acid, isobutyrate acid, and propionic acid) was analyzed by gas chromatography (HP 5890, Japan) with temperature of the column, detector, and injector were set at $60^{\circ} \mathrm{C}, 260^{\circ} \mathrm{C}$, and $250^{\circ} \mathrm{C}$, respectively. Agilent column FFAP capillary type had $30 \mathrm{~m}$ length. The carrier gas was helium.

\section{RESULTS AND DISCUSSION}

\section{Immobilized and Co-immobilized Beads Characterisation}

Shape of immobilized beads and co-immobilized with $1 \%, 2 \%$, and $3 \%$ of alginate concentrations which are presented in Figure 1 and Figure 2.

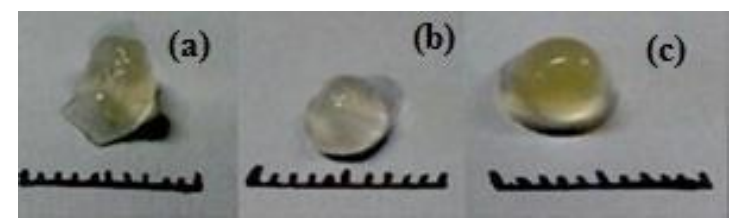

Figure 1. Immobilized beads with alginate concentration a) $1 \%$, b) $2 \%$, and c) $3 \%$ 
Figure 1 shows that the shape of immobilized beads with $1 \%$ alginate concentration (1a) was not spherical, while the beads spherical shape was obtained at 2 $\%(1 \mathrm{~b})$ and $3 \%(1 \mathrm{c})$ alginate concentration.

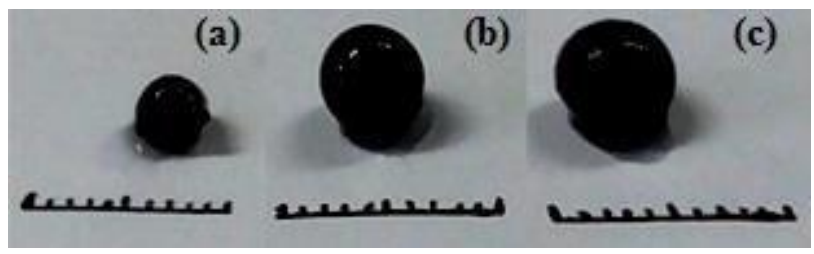

Figure 2. Co-immobilized beads with a) $1 \%$, b) $2 \%$ and c) $3 \%$ of alginate concentrations Figure 2 shows that shape of co-immobilized beads for all alginate concentrations were spherical, although Figure 2a was smaller than the two others. Co-immobilized and immobilized beads size and analysis of Ohnesorge number (Oh) of this experiment are presented in Table 2 and Table 3, respectively.

Table 2. Diameter of beads

\begin{tabular}{ccc}
\hline \multirow{2}{*}{ Alginate concentration $(\%)$} & \multicolumn{2}{c}{ Diameter of beads $(\mathrm{mm})$} \\
\cline { 2 - 3 } & Immobilized & Co-immobilized \\
\hline 1 & 3.9 & 4.1 \\
2 & 3.9 & 4.2 \\
3 & 4.2 & 4.3 \\
\hline
\end{tabular}

Table 3. Experimental conditions

\begin{tabular}{cccccc}
\hline $\begin{array}{c}\text { Alginate } \\
\begin{array}{c}\text { concentration } \\
(\%)\end{array}\end{array}$ & $\begin{array}{c}\text { Density } \\
\left(\mathrm{Kg} \cdot \mathrm{m}^{-3}\right)\end{array}$ & $\begin{array}{c}\text { Dinamic Viscosity } \\
\left(\mathrm{Kg} \cdot \mathrm{m}^{-1} \cdot \mathrm{s}^{-1}\right)\end{array}$ & $\begin{array}{c}\text { Surface Tension } \\
\left(\mathrm{Kg} \cdot \mathrm{m} . \mathrm{s}^{-2}\right)[33]\end{array}$ & $\begin{array}{c}\text { Nozzle } \\
\text { Diameter } \\
(\mathrm{m})\end{array}$ & Oh \\
\hline 1 & 999.424 & 0.00514 & 0.07 & 0.0022 & 0.013 \\
2 & 990.632 & 0.03132 & 0.07 & 0.0022 & 0.080 \\
3 & 989.189 & 0.09332 & 0.06 & 0.0022 & 0.258 \\
\hline
\end{tabular}

Table 3 shows that $1 \%$ and $2 \%$ alginate concentrations had $\mathrm{Oh}<0.24$, while $3 \%$ alginate concentration had $\mathrm{Oh}>0.24$. The average diameter of immobilized beads was $4.04 \mathrm{~mm}$, whereas that of the co-immobilized beads was $4.21 \mathrm{~mm}$. Generally, beads diameter was 1-5 $\mathrm{mm}$ [34]. The differences of diameters between the immobilized and co-immobilized beads were caused by gravity and surface tension imbalance when beads dropped from the tip dropper [35]. Consequently, if the beads diameter decreased, the surface tension also decreased. 
Beads shape was influenced by parameters including physical properties such as viscosity or alginate concentration, surface tension, the distance of dropper to gel solution, and stirring speed [30]. Characterization of beads size and shape were defined in a dimensionless number of Ohnesorge (Oh) (Eq. 1):

$$
\mathrm{Oh}=\frac{\eta}{\sqrt{\rho \mathrm{D} \gamma}}
$$

where $\eta$ surface tension of alginate solution $\left(\mathrm{kg} \cdot \mathrm{m}^{-1} \mathrm{~s}^{-1}\right), \rho$ is alginate solution density $\left(\mathrm{kg} \mathrm{m}^{-3}\right), \mathrm{D}$ is the diameter of the dropper $(\mathrm{m}), \gamma$ is the surface tension of alginate solution $\left(\mathrm{kg} \mathrm{m}^{-1} \mathrm{~s}^{-1}\right)$. If alginate concentration have $\mathrm{Oh}<0.24$ (example concentration alginate as $0.5 \mathrm{~g} \mathrm{~L}^{-1}$ ) so beads shape were deformed transition from tears to a ball, and then into egg-shape [35].

It shows that immobilized beads shape with $1 \%, 2 \%$ and $3 \%$ of alginate concentrations were not uniform (Figure 1), whereas all of co-immobilized beads shape was spherical (Figure 2). However, the Oh numbers in Table 3 indicated that both the immobilized and co-immobilized beads with $1 \%$ and $2 \%$ of alginate concentrations had the final shape like a pear, while the final shape of beads with $3 \%$ alginate concentration was spherical.

Co-immobilized beads shape with $3 \%$ alginate concentration was only $60 \%$ round-shaped and the rest of round noodles (Figure 3a) and tear shape (Figure 3b).

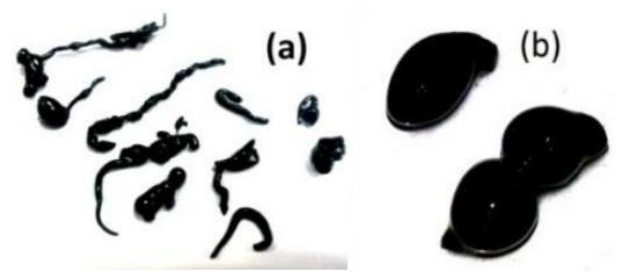

Figure 3. Co-immobilized beads form with $3 \%$ alginate concentration a) noodle-like; b) tear

Alginates with concentration below $1.5 \%$ produced non spherical and very fragile beads [36][37], whereas 2-3\% concentration of alginate produced spherical and strong beads[37]. A research by Kong et al. [38] demonstrated that the alginate concentration above $4 \%$ caused a very viscous solution, so it was difficult to produce spherical beads.

\section{Hydrogen Production Using Immobilized and Co-immobilized Beads}

Plot between both the beads (1\%,2\%, and 3\% of alginate concentrations) and hydrogen yields $\left(\mathrm{ml} \mathrm{H}_{2} / \mathrm{mol}\right.$ glucose) are presented in Figure 4. 


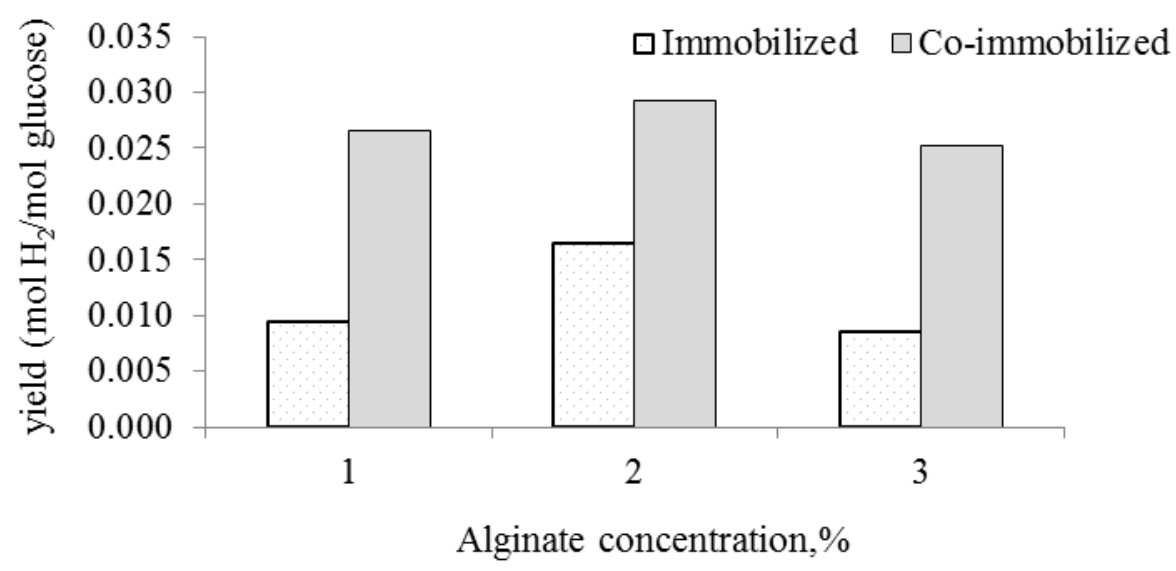

Figure 4. Alginate concentration (\%) toward hydrogen yields (mol of $\mathrm{H}_{2} / \mathrm{mol}$ glucose) for immobilized and co-immobilized beads.

Figure 4 shows that hydrogen yields ( $\mathrm{mol} \mathrm{H}_{2} / \mathrm{mol}$ glucose) for immobilized beads was $0.0095,0.017$, and 0.009, meanwhile for co-immobilized beads was 0.027 , 0.029 , and 0.025 . Figure 4 shows that the hydrogen yields ( $\mathrm{mol} \mathrm{H}_{2} / \mathrm{mol}$ glucose) on the co-immobilized bead is larger than the immobilized bead. It is assumed that alginate stability reduced due to chelate complex compound (for example, phosphates), cells growth in the beads, as well as the evolution of gas causing pressure inside the beads will rise so that the integrity of the gel was reduced [22][28]. Although microbes growth in both beads, but the presence of activated carbon in the co-immobilized beads was stronger than the immobilization beads [22][27].

The largest hydrogen yields ( $\mathrm{mol} \mathrm{H}_{2} / \mathrm{mol}$ glucose) was produced at $2 \%$ alginate concentration in both beads. It is assumed that $2 \%$ alginate concentration has sphericalshaped. Whereas hydrogen yields of co-immobilized beads for all alginate concentration have almost similar. It can be assumed that all alginate concentration of co-immobilized beads has spherical-shaped. The highest hydrogen production was for $3 \%$ of alginate concentration which was $0.029 \mathrm{~mol} \mathrm{H}_{2} / \mathrm{mol}$ glucose. It showed that activated carbon acted as a support for alginate matrix.

The average of immobilized and co-immobilized beads this study is less 100 times than Wu et al.(2002)[22] (Table 4). It is assumed that the microorganisms used in this study were $16.7 \%$, the alginate material was technical, and the concentration of $\mathrm{CaCl} 2$ was $50 \%$. 
Table 4. Comparative hydrogen yields of immobilized mixed culture used entrapment method in literature and present study in batch fermentation

\begin{tabular}{|c|c|c|c|c|c|c|}
\hline Microorganism & Substrate & $\begin{array}{l}\text { Temperature } \\
\left({ }^{\circ} \mathrm{C}\right)\end{array}$ & $\begin{array}{l}\text { Carrier } \\
\text { Material }\end{array}$ & $\begin{array}{l}\text { algiante } \\
\text { concentration }(\%)\end{array}$ & $\mathrm{H}_{2}$ Yield & Ref. \\
\hline \multirow[t]{2}{*}{ Sewage sludge } & sucrose & 35 & $\mathrm{CA}$ & 2 & $\begin{array}{c}1.7 \mathrm{molH}_{2} / \mathrm{mol} \\
\text { sucrose }\end{array}$ & [22] \\
\hline & & & $\mathrm{CA} / \mathrm{AC}$ & $2 / 2$ & $\begin{array}{c}2.6 \mathrm{molH}_{2} / \mathrm{mol} \\
\text { sucrose }\end{array}$ & \\
\hline \multirow[t]{2}{*}{$\begin{array}{l}\text { Three different } \\
\text { biodigester } \\
\text { sources }\end{array}$} & glucose & 36 & $\mathrm{CA}$ & 2 & $\begin{array}{c}0.017 \\
\text { molH } \\
\text { glucose }\end{array}$ & $\begin{array}{l}\text { This } \\
\text { study }\end{array}$ \\
\hline & & & $\mathrm{CA} / \mathrm{AC}$ & $2 / 2$ & $\begin{array}{c}0.029 \\
\mathrm{molH}_{2} / \mathrm{mol} \\
\text { glucose }\end{array}$ & \\
\hline
\end{tabular}

$\mathrm{CA}=$ calcium alginate; $\mathrm{AC}=$ activated carbon

\section{Effect of Alginate Concentration on VFA Production}

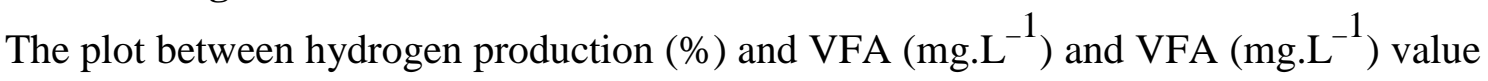
for co-immobilized beads and immobilized beads with $1 \%, 2 \%$ and $3 \%$ of alginate concentrations at the twentieth hour for glucose fermentation time are presented in Figure 5 and Table 5.
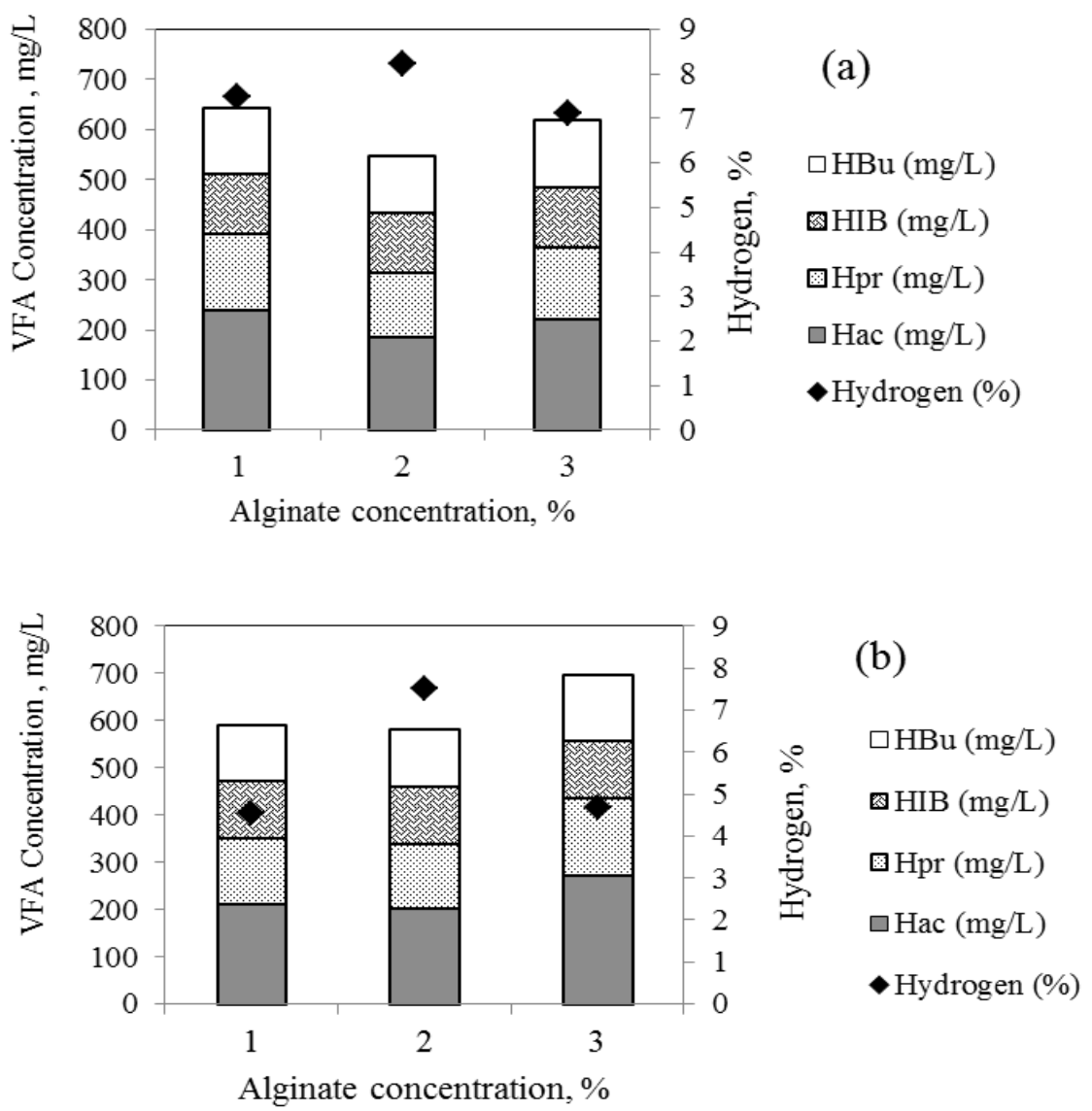

Figure 5. Concentration of VFA (mg.L $\left.{ }^{-1}\right)$ and $\mathrm{H}_{2}(\%)$ at the twentieth hour for glucose fermentation time with beads co-immobilized and immobilized. Hac: acetic acid; HPR: propionic acid; HIB: isobutyrate acid; HBU: butyric acid 
Figure 5 shows that VFA and hydrogen production for co-immobilized beads $1 \%$ alginat concentration was greater than immobilized beads. Two percentage alginate concentration of both beads for VFA was the lowest of the others, but its concentration was the highest hydrogen production. On the contrary, for immobilized beads, the VFA value was higher than co-immobilized beads but the hydrogen value is lower than the co-immobilized beads. Both are assumed that an effect on the metabolic pathway in the cells.

Table 5. VFA (mg/L) value for co-immobilized and immobilized beads

\begin{tabular}{ccccccccc}
\hline \multirow{2}{*}{$\begin{array}{c}\text { Alginate } \\
\text { concentration } \\
(\%)\end{array}$} & \multicolumn{3}{c}{ VFA (mg/L) for co-immobilized beads } & \multicolumn{3}{c}{ VFA (mg/L) for immobilized beads } \\
\cline { 2 - 9 } & Hac & Hpr & HIB & HB & Hac & Hpr & HIB & HB \\
\hline 1 & 239.09 & 150.09 & 120.78 & 132.92 & 210.43 & 139.79 & 123.11 & 117.51 \\
2 & 185.69 & 127.88 & 120.10 & 110.92 & 201.91 & 137.31 & 120.83 & 122.69 \\
3 & 220.87 & 143.92 & 119.75 & 132.19 & 271.49 & 163.33 & 123.45 & 137.57 \\
\hline
\end{tabular}

Glycolysis is the key of metabolic pathways in the cells in which the glucose is converted to pyruvate (intermediate metabolite). In anaerobic conditions, pyruvate reacts on acidogenesis and produce VFA include acetic acid, butyric acid, and propionic acid. Theoretically, the maximum yields of $\mathrm{H}_{2}$ if all glucose was converted to acetic acid was $4 \mathrm{~mol} \mathrm{H}_{2}$ per mole of glucose (Eq. 2) and butyric acid was $2 \mathrm{~mol} \mathrm{H}_{2}$ per glucose (Eq. 3). However, acetic acid was produced not only from glucose decomposition but also from the conversion of hydrogen and carbon dioxide (Eq. 4). While propionic acid formation consumed by hydrogen (Eq.5). Ethanol (Eq.6) and lactic acid (Eq. 7) were a by-product in addition to the carbon dioxide from glucose fermentation [39].

$$
\begin{aligned}
& \mathrm{C}_{6} \mathrm{H}_{12} \mathrm{O}_{6}+2 \mathrm{H}_{2} \mathrm{O} \rightarrow 2 \mathrm{CH}_{3} \mathrm{COOH}+4 \mathrm{H}_{2}+2 \mathrm{CO}_{2} \\
& \mathrm{C}_{6} \mathrm{H}_{12} \mathrm{O}_{6}+2 \mathrm{H}_{2} \mathrm{O} \rightarrow \mathrm{CH}_{2} \mathrm{CH}_{2} \mathrm{CH}_{2} \mathrm{COOH}+2 \mathrm{H}_{2}+2 \mathrm{CO}_{2} \\
& 2 \mathrm{CO}_{2}+4 \mathrm{H}_{2} \rightarrow \mathrm{CH}_{3} \mathrm{COOH}+2 \mathrm{H}_{2} \mathrm{O} \\
& \mathrm{C}_{6} \mathrm{H}_{12} \mathrm{O}_{6}+2 \mathrm{H}_{2} \rightarrow 2 \mathrm{CH}_{3} \mathrm{CH}_{2} \mathrm{COOH}+2 \mathrm{H}_{2} \mathrm{O} \\
& \mathrm{C}_{6} \mathrm{H}_{12} \mathrm{O}_{6} \rightarrow 2 \mathrm{CH}_{3} \mathrm{CH}_{2} \mathrm{OH}+2 \mathrm{CO}_{2} \\
& \mathrm{C}_{6} \mathrm{H}_{12} \mathrm{O}_{6} \rightarrow 2 \mathrm{CH}_{3} \mathrm{CHOHCOOH}+2 \mathrm{CO}_{2}
\end{aligned}
$$


Figure 5 shows that percentage of hydrogen from co-immobilized beads was greater than immobilized beads. It is assumed that all acetic acid was formed from hydrogen (Eq.4). The low percentage of hydrogen of this experiment was due to converted of glucose to carbon dioxide (Eq. 2, 3, 6, and 7).

\section{CONCLUSIONS}

Bead characteristics can be determined from the shape and size. The bead shape depends on the concentration of alginate. Alginate concentrations of $1 \%$ and $2 \%$ in immobilized beads tend to be pear-shaped, whereas co-immobilized beads shape for all alginate concentrations was generally spherical. The average diameter of the both beads was $4 \mathrm{~mm}$. The highest of hydrogen yields was obtained in co-immobilized beads with $2 \%$ alginate concentration, whereas the lowest hydrogen yields was immobilized beads with $3 \%$ alginate concentration. The hydrogen production was not proportional to VFA formation. Immobilized beads with $3 \%$ alginate concentration was the highest VFA whereas co-immobilized beads with $2 \%$ alginate concentration was the highest hydrogen production.

\section{REFERENCES}

[1] Gomez-Flores M, Nakhla G, Hafez H. Hydrogen production and microbial kinetics of Clostridium termitidis in mono-culture and co-culture with Clostridium beijerinckii on cellulose. AMB Express. 2017;7:84.

[2] Hallenbeck PC, Ghosh D, Skonieczny MT, Yargeau V. Microbiological and engineering aspects of biohydrogen production. Indian J Microbiol. 2009;49:4859.

[3] Dufour J, Serrano DP, GaLvez JL, Moreno J, Garc1 C. Life cycle assessment of processes for hydrogen production. Environmental feasibility and reduction of greenhouse gases emissions. Int J Hydrogen Energy. 2009;34:1370-6.

[4] Kotay SM., Das D. Biohydrogen as a renewable energy resource - Prospects and potentials. Int J Hydrogen Energy. 2008;33:258-63.

[5] Zhang L, Li J, Ban Q, He J, Jha AK. Metabolic pathways of hydrogen production in fermentative acidogenic microflora. J Microbiol Biotechnol. 2012;22:668-73.

[6] Patel SKS, Kalia VC. Integrative Biological Hydrogen Production: An Overview. Indian J Microbiol. 2013;53:3-10.

[7] Chandra R, Nikhil GN, Mohan VS. Single-stage operation of hybrid dark-photo fermentation to enhance biohydrogen production through regulation of system redox condition: Evaluation with real-field wastewater. Int J Mol Sci. 2015; 16:9540-56. 
[8] Hallenbeck PC, Hashesh MA, Ghosh D. Strategies for improving biological hydrogen production. Bioresour Technol. 2012;110:1-9.

[9] Chen W, Chen S, Kumarkhanal S, Sung S. Kinetic study of biological hydrogen production by anaerobic fermentation. Int J Hydrogen Energy. 2006;31:2170-8.

[10] Luque R, Campelo J, Clark J. Handbook of biofuels production: Processes and technologies. Woodhead Publishing Ltd.:Cambridge.pp.268; 2011.

[11] Dong L, Zhenhong Y, Yongming S, Xiaoying K, Yu Z. Hydrogen production characteristics of the organic fraction of municipal solid wastes by anaerobic mixed culture fermentation. Int J Hydrogen Energy. 2009;34:812-20.

[12] Amekan Y, Cahyanto MN, Sarto. Effect of Different Source of Inoculum to the Hydrogen Production from Melon Fruit Waste on Batch Fermentor. Conf. Proc. APCSLE CEAASC, Taipei, Taiwan. 2014, p. APCSLE - 342.

[13] Chen CC, Lin CY, Lin MC. Acid - base enrichment enhances anaerobic hydrogen production process. Appl Microbiol Biotechnol. 2002;58:224-8.

[14] Cheong DY, Hansen CL. Feasibility Of Hydrogen Production From Anaerobic Mixed Fermentation. Trans ASABE. 2006;49:467-76.

[15] Hu B, Liu Y, Chi Z, Chen S. Biological Hydrogen Production Via Bacteria Immobilized In Calcium Alginate Gel Beads. Trans ASABE. 2008;1:25-37.

[16] Marone A, Massini G, Patriarca C, Signorini A, Varrone C, Izzo G. Hydrogen production from vegetable waste by bioaugmentation of indigenous fermentative communities. Int J Hydrogen Energy. 2012;37:5612-22.

[17] Sivagurunathan P, Sen B, Lin CY. Batch fermentative hydrogen production by enriched mixed culture: Combination strategy and their microbial composition. $\mathbf{J}$ Biosci Bioeng. 2014;117:222-8.

[18] C-Y.Kumar G, Mudhoo A, Sivagurunathan P, Nagarajan D, Ghimire A, Lay C$\mathrm{H}$, et al. Recent insights into the cell immobilization technology applied for dark fermentative hydrogen production. Bioresour Technol. 2016;219:725-37.

[19] Sekoai P., Awosusi AA, Yoro KO, Singo M, Oloye O, Ayeni AO, et al. Microbial cell immobilization in biohydrogen production: a short overview. Crit Rev Biotechnol. 2017;0:1-15.

[20] Kumar A, Jain SR, Sharma CB, Joshi AP, Kalia VC. Increased H2 production microorganisms by immobilized. World J Mcrobiology Biotechnol. 1995;11:156-9. 
[21] Wu KJ, Chang JS. Biohydrogen Production Using Suspended and Immobilized Mixed Microflora. J Chin Inst Chem Engrs. 2006;37:545-50.

[22] Wu SY, Lin CN, Chang JS, Lee KS, Lin PJ. Microbial hydrogen production with immobilized sewage sludge. Biotechnol Prog. 2002;18:921-6.

[23] Sekoai P, Yoro K, Daramola M. Batch Fermentative Biohydrogen Production Process Using Immobilized Anaerobic Sludge from Organic Solid Waste. Environments. 2016;3:38.

[24] Dzionek A, Wojcieszyńska D, Guzik U. Natural carriers in bioremediation: A review. Electron J Biotechnol. 2016;23:28-36.

[25] Merugu R, Rudra MPP, Nageshwari B, Rao AS, Ramesh D. Photoproduction of Hydrogen under Different Cultural Conditions by Alginate Immobilized Rhodopsedomonas palustris KU003. ISRN Renew Energy. 2012;2012:1-5.

[26] Thakur V, Jadhav SK, Tiwari KL. Optimization of Different Parameters for Biohydrogen Production by Klebsiella oxytoca ATCC 13182. Trends Appl Sci Res. 2014;5:229-37.

[27] Mesran MH, Mamat S, Pang YR, Hong TY, Muneera Z, Ghazali NFM, et al. Preliminary Studies on Immobilized Cells-Based Microbial Fuel Cell System on Its Power Generation Performance. J Asian Sci Res. 2014;4:428-35.

[28] Azbar N, Kapdan IK. Use of Immobilized Cell Systems in Biohydrogen Production. In State of the Art and Progress in Production of Biohydrogen.Bentham Science Publishers.pp.231; 2012.

[29] Al-Hajry HA, Al-Maskry SA, Al-Kharousi LM, El-Mardi O. Electrostatic Encapsulation and Growth of Plant Cell Cultures in Alginate. Biotechnol Prog. 1999;15:768-74.

[30] Lee BB, Ravindra P, Chan ES. Size and Shape of Calcium Alginate Beads Produced by Extrusion Dripping. Chem Eng Technol. 2013:1627-42.

[31] Li D. Encyclopedia of Microfluidics and Nanofluidics. Springer: USA. pp.402; 2008.

[32] Jang D, Kim D, Moon J. Influence of fluid physical properties on ink-jet printability. Langmuir. 2009;25:2629-35.

[33] Damayanti A, Sarto, Syamsiah S, Sediawan WB. Biohydrogen production from rotten orange with immobilized mixed culture: Effect of immobilization media for various composition of substrates. vol. 1699, In International Conference of Chemical and Material Engineering (ICCME), Semarang, Indonesia.pp. 0300141-7: AIP Publishing; 2015.

[34] Willaert G.W. and Baron GV. Gel entrapment and micro-encapsulation: methods, applications and engineering principles. Willaert GW Baron, GV 1996;12:5-205. 
[35] Chan ES, Lee BB, Ravindra P, Poncelet D. Prediction models for shape and size of ca-alginate macrobeads produced through extrusion-dripping method. J Colloid Interface Sci. 2009;338:63-72.

[36] Seifert DB, Phillips JA. Production of Small, Monodispersed Alginate Beads for Cell Immobilization. Biotechnol Prog. 1997;13:562-8.

[37] Chen XH, Wang XT, Lou WY, Li Y, Wu H, Zong MH. Immobilization of Acetobacter sp . CCTCC M209061 for efficient asymmetric reduction of ketones and biocatalyst recycling. Microb Cell Fact. 2012;11:1-13.

[38] Kong HJ, Yong K, Mooney DJ. Decoupling the dependence of rheological / mechanical properties of hydrogels from solids concentration. Polymer (Guildf). 2002;43:6239-46.

[39] Karimi K. Lignocellulose- Based Bioproducts. Springer International Publishing:Switzerland.pp270; 2015. 